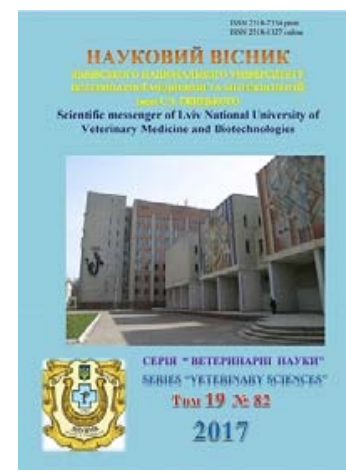

Науковий вісник Львівського національного університету ветеринарної медицини та біотехнологій імені С.З. Гжицького

Scientific Messenger of Lviv National University of Veterinary Medicine and Biotechnologies

doi:10.15421/nvlvet8219

ISSN 2518-7554 print

ISSN 2518-1327 online

$\underline{\text { http://nvlvet.com.ua/ }}$

УДК 619:618.19-002:615:637.12.07:632.2

\title{
Проблеми захворювань молочної залози та перспективи розробки нових протимаститних препаратів
}

\author{
I.M. Кушнір, С.Д. Мурська \\ igorku70@gmail.com
}

Державний науково-дослідний контрольний інститут ветеринарних препаратів та кормових добавок вул. Донецька, 11, м. Львів, 79019, Україна

\begin{abstract}
Mастит (Mastitis) - поліетіологічне захворювання, яке в переважній більшості випадків (95-98\%) виникає і розвивається внаслідок потрапляння в тканини вим'я патогенної мікрофлори, зокрема стафілококів, стрептококів, кишковоі палички тощо. Хвороби молочної залози корів завдають значних економічних збитків господарствам різної форми власності, які полягають у не доодержуванні молока, зниженні його якості та вибраковиі корів, в першу чергу високопродуктивних. Крім того, вживання молока від хворих корів на мастит загрожує здоров ю людей, що є неприпустимим.

Мастити трапляються, як у високопродуктивних, так і низькопродуктивних тварин, як у період лактаиії, так $і$ в сухостійний період незалежно від періоду року. 3 усіх захворювань, зареєстрованих на великих молочно-товарних, племінних і фермерських господарствах з різною формою власності найбільше поширення мають мастити. Корови найчастіше хворіють на мастит у перші дні післяродового періоду або через 10-15 діб після отелення, а також у період посиленої лактаиії.

Виділяємо, щео створення нових й удосконалення існуючих протимаститних засобів здійснюється, як правило, шляхом розробки багатокомпонентних препаратів, до складу яких входять декілька активно діючих речовин із різних класів хімічних сполук, які повинні взаємодоповнювати одна одну в спектрі протимікробної активності.

Саме тому, є необхідність у проведенні перспективних досліджень із створення ефективніших протимаститних препаратів, при чому тих, які б не залишали залишків у тканинах і продукиії.

Ключові слова: мастити, молочна залоза, мікрорганізми, мікрофлора, культура, збудник, діагностика, протимаститні препарати.
\end{abstract}

\section{Problems of mammary gland diseases and prospects for the development of new anti mastitis preparations}

\author{
I.M. Kushnir, S.D. Murska \\ igorku70@gmail.com
}

State scientific research control institute of veterinary preparations and feed additives, Donetska Str., 11, Lviv, 79019, Ukraine

\begin{abstract}
Mastitis (Mastitis) is a polyethiological disease, which in most cases (95-98\%) occurs and develops as a result of ingestion of pathogenic microflora in the udder tissue, in particular staphylococci, streptococci, E. coli etc. Diseases of the mammary gland of cows cause significant economic losses to farms of different forms of property, which consist in not getting milk, reducing its quality and crayfish cows, in the first place high-yielding. In addition, the use of milk from cows sick for mastitis threatens the health of people, which is unacceptable.

Mastitis occur in both high-yielding and low-productive animals, both, during lactation and in the dry period, regardless of the period of the year. The most widespread, out of all the diseases registered in large dairy commodities, tribal and farms with different
\end{abstract}

Citation:

Kushnir, I.M., Murska, S.D. (2017). Problems of mammary gland diseases and prospects for the development of new anti mastitis preparations. Scientific Messenger LNUVMB, 19(82), 93-96. 
forms of ownership is mastitis. Cows most often suffer from mastitis in the first days of the postnatal period, or 10-15 days after calving, as well as in the period of intense lactation.

We emphasize that the creation of new and improved existing anti-mastics preparations, as a rule, are done through the development of multicomponent preparations, which include several active substances from different classes of chemical compounds, which must complement each other in the spectrum of antimicrobial activity.

Owing to this, there is a need for advanced research on the creation of more effective anti-mastitis preparations, while those which would not leave residues in tissues and products.

Taking into account all abovementioned, the microbiological studies were conducted on 29 samples of milk from cows suffering from clinical and subclinical mastitis in the detection of pathogens. In particular, it was found that for the clinical form of the mastitis, the most commonly isolated monoculture was Staphylococcus aureus (33.7\%), Streptococcus agalactiae (29.4\%), and in the association of Streptococcus agalactiae and Staphylococcus aureus (22.5\%). In the subclinical form of mastitis, the following cultures were identified in the association: Staphylococcus aureus, Staphylococcus epidermidis, Streptococcus agalactiae and Streptococcus dysgalactiae (41.6\%); Streptococcus dysgalactiae, Streptococcus agalactiae and Streptococcus uberis (30.4\%) Staphylococcus aureus and Staphylococcus epidermidis (24.1\%).

Key words: mastiti, mammary gland, microrganisms, microflora, culture, exciter, anti mastitis preparations.

\section{Вступ}

Причин виникнення маститів дуже багато, врахувати їх всіх не можливо, тому необхідно виділити основні фактори: резистентність організму корови і іiі молочної залози, наявність і ступінь патогенності збудників, умови годівлі, утримання, експлуатації, дії стресових факторів і особливо доїння (Oksamitnyj and Mohammed, 1989; Iablonskyi et al., 2011).

Відповідно до етіології всі мастити можна розділити на дві основні групи: інфекційні, що виникають в результаті впливу мікроорганізмів на молочну залозу, неінфекційні, що з'являються за фізичного або хімічного травмування вим'я, неправильному доїнні тощо. Вони характеризуються патологічними змінами як у тканинах, так і в секреті молочної залози. Мікроби можуть бути причиною або ускладнювати перебіг запального процесу за ослаблення резистентності тканин вимені і зниженні активності бактеріальних факторів молока. Найбільш часто з вимені при маститах виділяють стафілококи, стрептококи, значно рідше кишкову паличку, сальмонели, мікоплазми, гриби, віруси, як в монокультурі, так і в асоціації (Oksamitnyj and Mohammed, 1989; Ivashura, 1991; Nezhdanov et al., 2005).

Мікроби в молочну залозу проникають, в основному, трьома шляхами: лактогенний (через канал соска i при недотриманні ветеринарно-санітарних правил утримання тварин); лімфогенний (через тріщини на шкірі молочної залози) та гематогенний (з потоком крові при атонії і субінволюції матки, затриманні посліду, ендометритах). При кормових отруєннях через кровоносні і лімфатичні судини у вим'я можуть потрапити токсини, що також сприяє розвитку запалення молочної залози. До фізичних факторів належать: дія низьких та високих температур (охолодження, відмороження, опік, підвищена вологість у приміщеннях та на вигульних майданчиках) (Ivashura, 1990; Parikov and Klimov, 2000).

Широке поширення хвороби пояснюється фізіологічними навантаженнями на організм високопродуктивних корів, розладами за машинного доїння, утриманні та годівлі, а також недотриманням ветеринарно-санітарних вимог. 3 підвищенням технологічних вимог до молока виникла гостра необхідність створення нових програм, засобів і способів із профілактики та лікування корів із маститами (Nezhdanov et al., 2005; Parikov and Klimov, 2000). Розробка, випробування і виробництво нових комплексних, ефективніших і не дорогих препаратів, дозволить удосконалювати схеми лікування хворих тварин, і таким чином, підвищити рентабельність тваринництва. Аналіз літератури показує, що, незважаючи на значні успіхи у вивченні етіології маститу корів, його патогенезу, клінічних проявів цього захворювання, розробки методів профілактики та лікування, ця патологія завдає значних економічних збитків тваринництву, що визначає іiі актуальність та важливість всебічного вивчення (Golovko et al., 2000; Dosogne et al., 2002; Slobodjanik, 2010)..

Мастит корів широко поширений в усіх країнах світу і завдає значного економічного збитку молочному скотарству. Успішне вирішення проблеми боротьби 3 маститом корів можливе за наявності сучасних i достовірних даних про форми і масштаби захворювання. Отримати таку інформацію можливо за допомогою методів діагностики, мастито стійкості і мастито сприйнятливості, що $є$ невід'ємним для вибору своєчасного і ефективного лікування корів хворих на мастит (Oksamitnyj and Mohammed, 1989; Zvierieva et al., 2000; Nezhdanov et al., 2005; Iablonskyi et al., 2011).

Удосконалення існуючих методів діагностики маститу корів, а також розробка нових - досі залишаються в центрі уваги значної кількості дослідників. У зв'язку з цим, дуже перспективною є розробка і впровадження у ветеринарну практику сучасних скринінгових методів, зокрема імуноензимного аналізу, який у світовій практиці знайшов широке застосування для ранньої діагностики мікробних і вірусних інфекцій (Ivashura, 1990; Nezhdanov et al., 2005; Iablonskyi et al., 2011).

Останнім часом доведено, що у виникненні і розвитку маститу корів велике значення мають біологічні особливості організму, що проявляється в мастито стійкості і мастито сприйнятливості. Проте, наявні розробки з цього питання у вітчизняній літературі носять лише статистичний характер і односторонньо виражають цю проблему (Ivashura, 1990; Parikov and Klimov, 2000; Golovko et al., 2000; Slobodjanik, 2010).

Ефективність лікування корів за маститів знаходиться в прямій залежності від своєчасності і послідовності надання лікувальної допомоги. Важливо не лише ліквідувати вогнище запалення, але й уникнути 
рецидиву, не допустити поширення захворювання на інші чверті вимені, зберегти продуктивність тварини. Лікування проводять з урахуванням форми та перебігу захворювання. Серед великого арсеналу терапевтичних засобів для лікування маститу особливе поширення мають антибіотики (Dosogne et al., 2002; Kuzmich, 2007; Jemeljanovs et al., 2007; Slobodjanik, 2010).

Проте, останнім часом ученими багатьох країн світу виявлений ряд істотних негативних наслідків лікування корів антибіотичними засобами у терапії маститу. Залишки антибіотиків у продукції становлять загрозу здоров'ю людей та виникають нові проблеми такі як дисбактеріози тощо. Власне тому, дослідниками основна увага приділяється розробці лікувальних препаратів, що не містять антибіотиків. Нині на озброєнні у практичних працівників практично відсутні ефективні лікувальні засоби, що не містять антибіотичних і інших хімічних речовин (Ivashura, 1990; Golovko et al., 2000; Dosogne et al., 2002; Slobodjanik, 2010). У цьому плані особливої уваги заслуговують препарати, які найбільш безпечно і ефективно відповідають вимогам, що пред’являються до лікувальних засобів для корів із маститом, а саме: нешкідливість для організму тварин і довкілля, висока терапевтична ефективність, безпека для здоров'я людей (Golovko et al., 2000; Kuzmich, 2007; Slobodjanik, 2010).

Захист господарств від небезпечних бактеріальних і вірусних патогенів, які спричиняють зниження продуктивності сільськогосподарських тварин і значні економічні збитки є пріоритетним завданням ветеринарної медицини. Профілактика та ліквідація хвороб вимені тварин , забезпечення стійкого благополуччя тваринництва, його високої продуктивності та санітарної якості продукції передбачає проведення своєчасної та ретельної профілактики, для чого можуть також бути використані вищезгадані сполуки (Nezhdanov et al., 2005; Iablonskyi et al., 2011).
Пошукові дослідження 3 використанням нових протимастиних препаратів повинні бути чітко сплановані, особливо у аспекті визначення їх безпечності та якості. Саме тому, на нашу думку план таких досліджень повинен включати:

- мету досліджень;

- завдання досліджень;

- аналіз доступних даних про спектр дії новостворенного препарату;

- методи досліджень;

- опис тест-систем, які можуть використовуватись у дослідженнях;

- схему досліджень із конкретизацією етапів;

- показники, які будуть обов'язковими для лабораторних досліджень;

- критерії оцінки ефективності препаратів;

- протоколювання всіх етапів досліджень 3 наступним оформленням заключного звіту.

Отже, створення нових й удосконалення існуючих протимаститних засобів здійснюється, як правило, шляхом розробки багатокомпонентних препаратів, до складу яких входять декілька активно діючих речовин iз різних класів хімічних сполук, які повинні взаємодоповнювати одна одну в спектрі протимікробної активності. Значний рівень резистентності мікроорганізмів до антибіотиків потребує пошуку нових сполук 3 антимікробною дією та розробки нових ефективніших лікарських засобів. Це і становить актуальність в розроблені нових протимаститних препаратів.

\section{Результати та їх обговорення}

На початковому етапі наших досліджень було проведено дослідження 29 проб молока корів, хворих на клінічну та субклінічну форму маститу. Результати досліджень наведено в таблицях 1 та 2.

Виділені збудники маститу корів за клінічної форми, $\mathbf{n}=29$

\begin{tabular}{|l|c|c|}
\hline \multicolumn{1}{|c|}{ Виділені збудники } & Кількість & $\%$ \\
\hline Streptococcus agalactiae & 8 & 29,4 \\
\hline Escherichia coli & 2 & 8,6 \\
\hline Streptococcus agalactiae + Staphylococcus aureus & 5 & 22,5 \\
\hline Staphylococcus aureus + Escherichia coli & 3 & 3,6 \\
\hline Staphylococcus aureus & 9 & 33,7 \\
\hline Pseudomonas aeruginosa & 2 & 2,2 \\
\hline
\end{tabular}

Таблиия 2

Виділені збудники маститу корів за субклінічної форми, $\mathbf{n}=29$

\begin{tabular}{|l|c|}
\hline Виділені збудники & Кількість \\
\hline $\begin{array}{l}\text { Staphylococcus aureus + Staphylococcus epidermidis + Streptococcus agalactiae + } \\
\text { Streptococcus dysgalactiae }\end{array}$ & 12 \\
\hline Staphylococcus aureus + Streptococcus agalactiae + Escherichia coli & 41,6 \\
\hline Streptococcus dysgalactiae + Streptococcus agalactiae + Streptococcus uberis & 3,9 \\
\hline Staphylococcus aureus + Staphylococcus epidermidis & 8 \\
\hline
\end{tabular}


Як видно з даних таблиць 1 та 2, домінуючу роль у виникненні маститів відіграли стрептококи та стафілококи. Найчастіше виділяли Staphylococcus aureus, Streptococcus agalactiae, Escherichia coli як в монокультурі, так і в асоціації.

Однак, після аналізу виділених збудників із молока хворих тварин, встановили, що за клінічної форми маститу частіше виділяли: Staphylococcus aureus (33,7\%), Streptococcus agalactiae (29,4\%), Escherichia coli $(8,6 \%)$ Pseudomonas aeruginosa (2,2\%) та в асоціаціï Streptococcus agalactiae i Staphylococcus aureus (22,5\%); Staphylococcus aureus та Escherichia coli $(3,6 \%)$. За виникнення субклінічного маститу виявили такі асоціації: Staphylococcus aureus та Staphylococcus epidermidis (24,1\%), Staphylococcus aureus, Staphylococcus epidermidis, Streptococcus agalactiae та Streptococcus dysgalactiae (41,6\%), Streptococcus dysgalactiae, Streptococcus agalactiae та Streptococcus uberis (30,4\%), Staphylococcus aureus, Streptococcus agalactiae та Escherichia coli (3,9\%).

\section{Висновки}

1. Встановлено, що молоко від корів, хворих на мастит, майже в усіх випадках містило значну кількість умовно-патогенних мікроорганізмів. За цих умов, домінуючу роль у спектрі цих мікроорганізмів відігравали стрептококи і стафілококи, найчастіше виділялись такі культури: Staphylococcus aureus, Streptococcus agalactiae, Escherichia coli як в монокультурі, так і в асоціації.

2. За клінічної форми маститу частіше у монокультурі виділяли: Staphylococcus aureus (33,7\%), Streptococcus agalactiae (29,4\%), а в асоціації Streptococcus agalactiae i Staphylococcus aureus (22,5\%). За субклінічної форми маститу виділяли такі культури в асоціації: Staphylococcus aureus, Staphylococcus epidermidis, Streptococcus agalactiae та Streptococcus dysgalactiae (41,6\%); Streptococcus dysgalactiae, Streptococcus agalactiae та Streptococcus uberis (30,4\%) Staphylococcus aureus та Staphylococcus epidermidis $(24,1 \%)$.

Перспективи подальших досліджень. Дослідження ефективності новостворенного протимаститного препарату на основі нанотехнологій.

\section{Бібліографічні посилання}

Zvierieva, H.V., Khomyn, S.P., Tyranovets, V.I. (2000). Akusherska i hinekolohichna dyspanseryzatsiia u systemi profilaktyky neplidnosti ta mastytiv u koriv. Zbirnyk naukovykh prats Natsionalnoho ahrarnoho un-tu : «Problemy fiziolohii i patolohii vidtvorennia tvaryn». K. 22, 21-28 (in Ukrainian).

Oksamitnyj, N.K., Mohammed, Je.T. (1989). Biologicheskaja diagnostika mastita. Veterinarija. 7, 50-52 (in Russian).

Iablonskyi, V.A., Khomyn, S.P., Kalynovskyi, H.M. (2011). Veterynarne akusherstvo, hinekolohiia ta biotekhnolohiia vidtvorennia tvaryn $\mathrm{z}$ osnovamy androlohii. Pidruchnyk. Vinnytsia: Nova knyha (in Ukrainian).

Ivashura, A.I. (1991). Sistema meroprijatij po bor'be s mastitami korov. M.: Rosagropromizdat (in Russian).

Nezhdanov, A.G., Slobodjanik, V.I., Hodakov, A.V. (2005). Morfo-fiziologicheskie osnovy laktacii i bolezni molochnoj zhelezy sel'skohozjajstvennyh zhivotnyh: ucheb. posobie. Voronezh: VGAU (in Russian).

Parikov, V.A., Klimov, N.T. (2000). Mastit u korov. Veterinarija. 11, 34-37 (in Russian).

Ivashura, A.I. (1990). Ispol'zovanie antimikrobnyh preparatov dlja lechenija korov, bol'nyh mastitom. Voprosy veterinarnoj farmacii i farmakoterapii. Sigulda, 39-41 (in Russian).

Slobodjanik, V.I. (2010). Immunologicheskie aspekty reshenija problemy mastita $u$ korov. Veterinarija sel'skohozjajstvennyh zhivotnyh. 10, 17-21 (in Russian).

Golovko, A.N., Vechtomov, V.Ja., Kuz'min, A.A. (2000). Lechenie korov bol'nyh mastitami. Mizhvidomchij tematichnij naukovij zbirnik. 77, 79-84 (in Russian).

Dosogne, H., Meyer, E., Sturk, A. (2002). Effect of enrofloxacin treatment on plasma endotoxin during bovine Escherichia coli mastitis. Inflammation Research. 51, 201-205.

Kuzmich, R.G. (2007). Problems of Mastitis in Cows on the Farms of the Resbublic of Belarus. Animal farming in transition - the role of animal reproduction: Mastitis symposium.

Jemeljanovs, A., Konosonoka, I.H., Dulbinskis, J. (2007). Mastitis Pathogenegis Agents' Spectrum in Cows Milk. Animal farming in transition - the role of animal reproduction: Mastitis symposium. 19, 17.

Received 29.09.2017 Received in revised form 23.10.2017 Accepted 3.11.2017 